
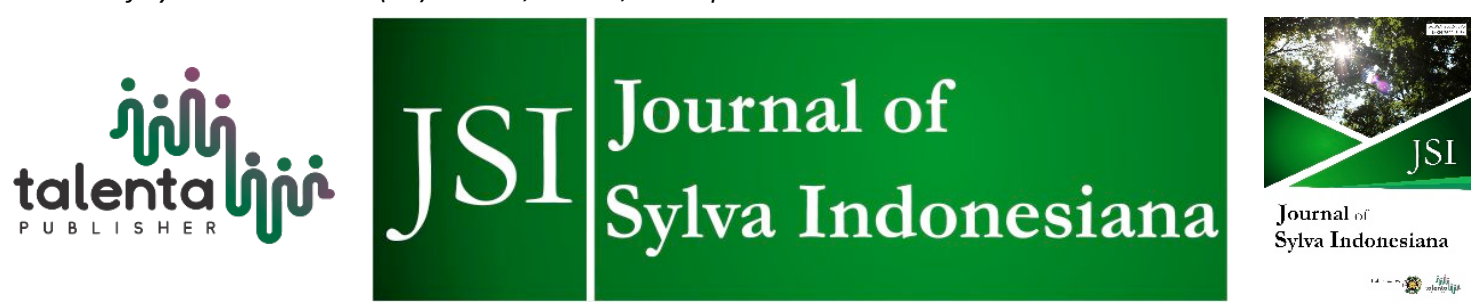

\title{
Forest Structure of 26-Year-Old Planted Mangroves
}

\author{
Ruhuddien Pandu Yudha ${ }^{1 *}$ \\ ${ }^{I}$ Forestry Department, PT. Bintuni Utama Murni Wood Industries, Jakarta, Indonesia
}

\begin{abstract}
The mangrove ecosystem in Bintuni Bay, West Papua, Indonesia has been utilized for its timber for more than three decades. Since there are only few mangrove areas that utilized for logging in Indonesia, data on growth and forest structure of post-harvest mangrove forest could become valuable information as a reference for sustainable management on the ecosystem. This study aims to observe forest structure and dynamics of planted mangroves after 26 years of growth. The study was conducted at a 1.6 ha permanent plot established and planted in 1994 using 5 dominant and commercial mangrove species in Bintuni Bay. Measurement of diameter was carried out for all stems occurred in each trees within the plot. Rhizophora apiculata has the best growth (volume of $594.85 \mathrm{~m}^{3} \mathrm{ha}^{-1}$ and biomass of 480.24 ton ha ${ }^{-1}$ ) and Ceriops tagal experienced the poorest growths (volume of $28.89 \mathrm{~m}^{3} \mathrm{ha}^{-1}$ and biomass of 23.11 ton ha ${ }^{-1}$ ). Average volume for five planted species was estimated to be $310.99 \mathrm{~m}^{3} \mathrm{ha}^{-1}$ with biomass of 247.08 ton ha $\mathrm{ha}^{-1}$. From all trees individual, $24.27 \%$ were categorized as multi stem trees with maximum of 8 stems that could occur from one single tree and contributed to increase total volume of the stands up to $33 \%$. In general, forest structure was not significantly different in various spacing distance. Planted mangroves can provide sufficient standing stock for future utilization in managed mangrove forests.
\end{abstract}

Keyword: Bintuni Bay, Silviculture, Spacing Effect, Sustainable Mangrove Management Received 24 February 2021 | Revised 12 June 2021 | Accepted 15 June 2021

\section{Introduction}

Mangrove ecosystem in Bintuni Bay, West Papua, Indonesia has been managed by a Forest Management Enterprise (FME) for more than three decades for timber extraction to produce wood chip [1]-[2] and must comply the framework of sustainable forest management standards [3]-[4]. The license for timber utilization to the company was granted by the Government of Republic of Indonesia in 1988 and was extended in 2007 until 2045 [5]. Recently, the FME has completed the first 30-year rotation cycle and standing stock of secondary forests in the end of the first cycle (30-year-old stand) was estimated to be $301.08 \mathrm{~m}^{3} \mathrm{ha}^{-1}$ [6]. However, the availability of primary mangrove forests within the concession area of 39,487.24 ha [7], drive

\footnotetext{
*Corresponding author at: Forestry Department, PT. Bintuni Utama Murni Wood Industries, Jl. Raya Rawa Domba No. 5, Jakarta Timur 13440, Indonesia E-mail address: ruhuddien_py@yahoo.com

Published by Talenta Publisher, p-ISSN: 2622-5093 e-ISSN: 2622-5158 DOI: 10.32734/jsi.v4i02.5680

Journal Homepage: http://jsi.usu.ac.id
} 
the FME to first utilize from those forests rather than secondary forests in the second rotation [8]-[10] while providing extension time to gain more incremental growth [6].

The silviculture system applied in the first rotation cycle was Sistem Pohon Induk [11] or parent trees method which accommodated natural regeneration to grow intensively in logged-over area so the stands could become more ecologically resilient from various perturbations [12]. Growth dynamics of natural regeneration in logged-over areas which supported by afforestation has been well documented in several studies within the concession area. Results from previous studies suggest that secondary forests experienced significant growth and has become the second generation of mangrove forests in Bintuni Bay after harvested in the first rotation cycle [1],[6],[13]-[15], with recovery time of 30-40 years to become similar with primary forests condition [13]. However, mangrove regeneration dynamics in Bintuni Bay that grows purely from planting has not being fully studied yet.

In 1994, a permanent plot was established in the concession area and planted using 5 dominant and commercial mangrove species. Measurement result from these plots can be used to describe forest structure and growth rate of mangroves that purely planted in logged-over areas without natural regeneration support from the parent trees. The purpose of this study was to observe forest structure and dynamics of planted mangroves after 26 years of growth. The results are useful as an input and reference for species determination in afforestation as part of silviculture system implementation in managed mangrove forests.

\section{Methods}

\subsection{Study Area}

The study was conducted within concession area of PT. Bintuni Utama Murni Wood Industries (PT. BUMWI) in Bintuni Bay, West Papua, Indonesia. Bintuni Bay covered with more than 220,000 ha mangroves and become the second largest stretches in Indonesia [16], while Indonesia has 1.6 million ha which represented over $20 \%$ of world mangrove ecosystem [17]. Approximately 82,120 ha of mangroves and surrounding area in the southern part of the bay are actively under management of PT. BUMWI since 1988 [5]. The permanent plot located in Amutu Besar Island on the center of concession area (red circle, Figure 1.a). Annual rainfall in Bintuni Bay is $2,849 \mathrm{~mm}$ with 218 rainy days, while air temperature is between $26.6-28.2{ }^{\circ} \mathrm{C}$ with average humidity of $82 \%$ [18]. Based on Schmidt \& Ferguson, the climate is classified as very wet (type A). Over $80 \%$ of soil in the concession area is categorized as Sulfaquent [19].

According to MoEF RI [7], 80\% of total concession area covering 62,945.77 ha is classified as mangrove ecosystems, while $20 \%$ is composed by terrestrial forest, nypa, sago and peat. Twenty-eight true mangrove species have been identified within the concession area with Rhizophoraceae as the most dominant family which contribute 9 species from genus of 
Rhizophora, Bruguiera and Ceriops [1]. As one of the largest mangrove stretches in the world [16], mangrove of Bintuni Bay has become valuable habitat for various flora and fauna which depend on the ecosystem, including 20 migrant birds from Australia, Palearctic and elsewhere in northern Asia [1],[20]. There are 34 birds in the area that categorized as endemic species which can only found in New Guinea big island and surrounding satellite islands [1].

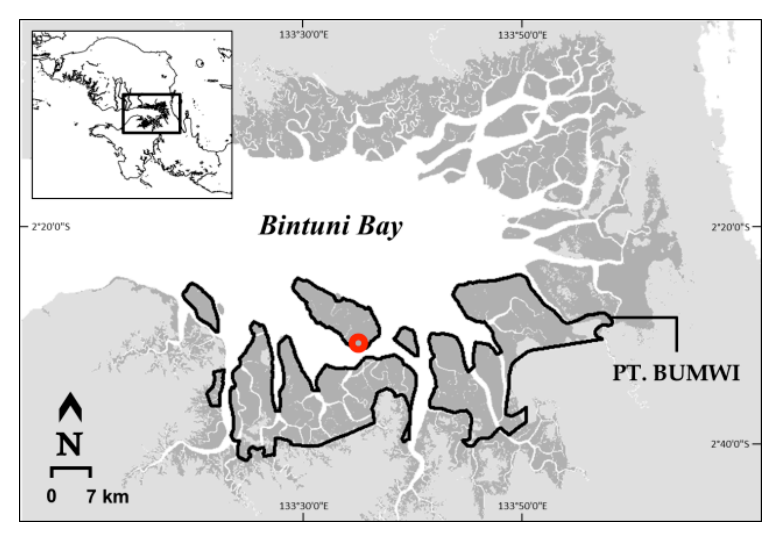

(a)

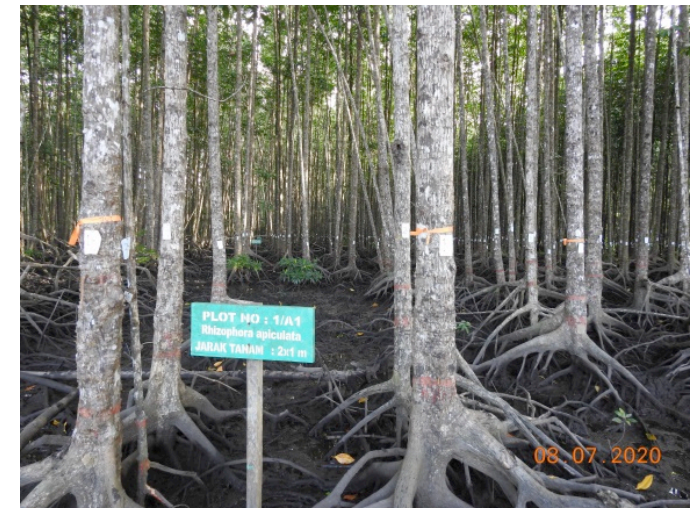

(b)

Figure 1 Area of Study. (a) Location of the FME in the southern part of Bintuni Bay, West Papua, Indonesia. Dark grey representing mangroves and wetland ecosystems while permanent plot of the study (red circle) located in Amutu Besar Island. (b) View of the permanent plot.

\subsection{Methods}

The permanent plot was established in 1994 and planted with 5 dominant and commercial mangrove species; Rhizophora apiculata, Rhizophora mucronata, Bruguiera parviflora, Bruguiera gymnorhiza and Ceriops tagal. For each species, 4 type of spacing were used as experimental block design; 1x2 m, 1x3 m, 2x2 m and 2x3 m. Each type of spacing occupied planting area of 20x20 m (quadrat plot), thus 1 species has 4 plot of 20x20 m with different type of spacing on each quadrat plot. Permanent plot for 5 species with 4 different spacing was established in 1 block of 0.8 ha (total 20 quadrat plot of 20x20 m). This block then replicated with the same size and spacing design which located beside the first block. Three blocks of permanent plot were established but only 2 blocks of 1.6 ha that were used for this study. Measurement of the stands within permanent plot was carried out in July 2020. Measurement of diameter breast high (DBH) was carried out for all individual trees. If one individual tree has more than one main stem (the main stem branched below DBH), then categorized as multi stem tree. All stems in multi stem trees were measured and included in the analysis to obtain total volume and biomass of the stand as implemented by [21].

\subsection{Data Analysis}

Data of measurement was calculated and summarized to analyze forest structure of the stands consisted of volume, density, basal area, and DBH size as well as extractable biomass. Total volume and biomass were obtained using allometry developed by [22] which made from 
mangrove stands within concession area. Allometry of biomass is only limited to estimate dry weight of logs that can be utilized (beside roots, branches and leaves), thus it does not represents total biomass above ground. Analysis of variance (ANOVA) or Kruskal-Wallis analysis was implemented to determine differences of mean forest structure in different spacing types while t-test was used to observe the difference of specific item on forest structure among species (e.g. to compare volume of $\mathrm{R}$. apiculata between blocks). Statistical analysis was carried out using $\mathrm{R}$ version 3.4.4.

\section{Results and Discussion}

\subsection{Forest Structure}

Average volume and extractable biomass for all species in the permanent plot were estimated to be $310.99 \mathrm{~m}^{3} \mathrm{ha}^{-1}$ and 247.08 ton ha ${ }^{-1}$ consecutively, with basal area of $35.95 \mathrm{~m}^{2} \mathrm{ha}^{-1}$ and stem density of 3,566 stem ha ${ }^{-1}$ (Figure 1). Average DBH on the age was $10.32 \mathrm{~cm}$. Individual of trees that survived and available within the permanent plot was $59.51 \%$ from total seedlings planted in 1994 (planted: 5,760 seedlings, survived: 3,428 trees), out of which 24.27\% of the available trees was categorized as multi stem trees with maximum 8 stems that could occurred from one single tree. Multi stem trees were significantly raised stem density as total individual of trees was only 2,143 trees ha-1 (Figure 1.e), while total stem density on the stand was 3,566 stem ha-1 (Figure 1.f). Mean forest structure on different spacing type was not significantly different $(\mathrm{p}>0.05)$. Thus, spacing for initial stocking post-harvest could be carried out in various options although the Government regulation directed to use $2 \times 2 \mathrm{~m}$ spacing distance to obtain minimum stocking of 2,500 seedlings $\mathrm{ha}^{-1}[11]$.

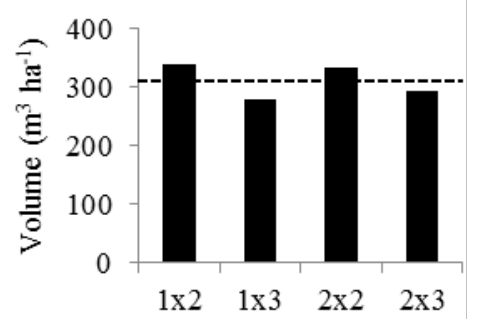

(a)

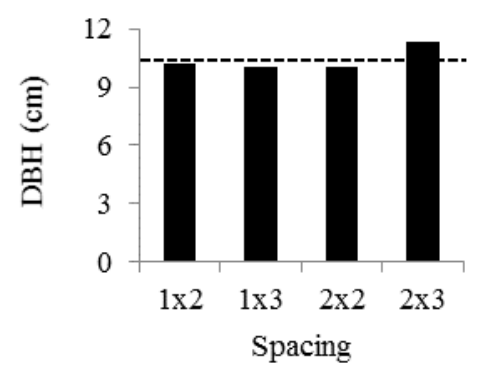

(d)

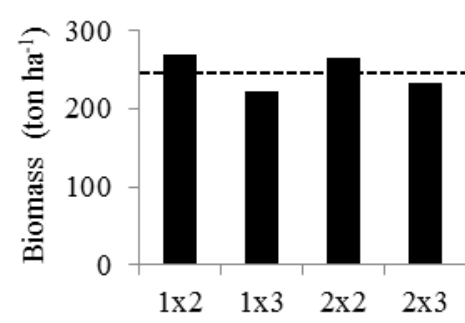

(b)

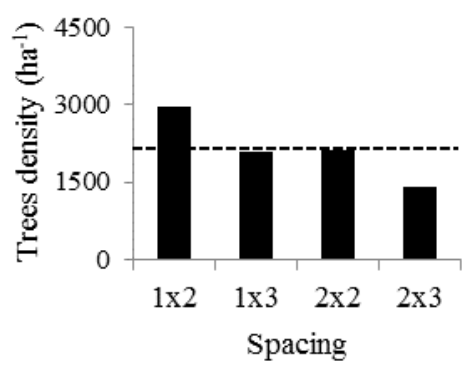

(e)

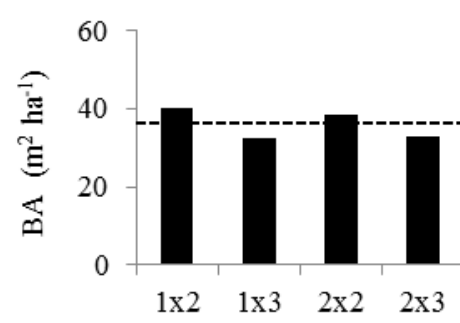

(c)

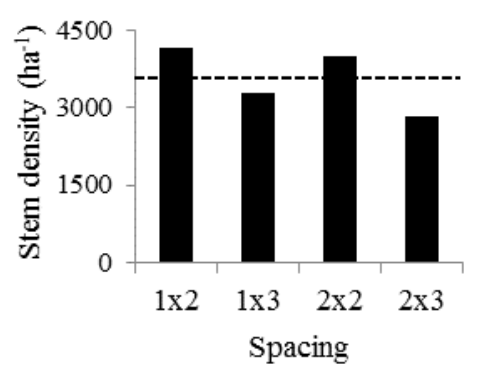

(f)

Figure 2 Forest structure of 26-year-old planted mangroves in different spacing type for 5 dominant and commercial species in Bintuni Bay, West Papua, Indonesia. (a) Volume $\left(\mathrm{m}^{3} \mathrm{ha}^{-1}\right)$. (b) Extractable biomass (ton ha $\left.{ }^{-1}\right)$. (c) Basal area/BA $\left(\mathrm{m} 2 \mathrm{ha}^{-1}\right)$. (d) Average DBH $(\mathrm{cm})$. (e) Trees density $\left(\right.$ trees ha $\left.{ }^{-1}\right)$. (f) Stem density $\left(\right.$ stem ha $\left.{ }^{-1}\right)$. Horizontal dash line representing average value. 
The results show that 5 dominant mangrove species in Bintuni Bay which planted 26 years ago have grown and provided sufficient standing stock for utilization, while the forest structure has approached primary forests condition. Average volume, stem density and DBH in primary mangrove forests of Bintuni Bay are $393.82 \mathrm{~m} 3 \mathrm{ha}^{-1}, 474.44$ stem ha $^{-1}$ and $29.64 \mathrm{~cm}$ consecutively [1]. Results from this study show that average volume has reach $78.96 \%$ of volume in primary forest, even though average DBH in the permanent plot was only $10.32 \mathrm{~cm}$. Therefore, multi stem trees seem have significant role in increasing total volume of the stand since stem density within the plot was 7 times higher than primary forest $(3,566$ stem ha- 1 compare to 474.44 stem $\mathrm{ha}^{-1}$ in primary forests).

Multi stem trees in secondary mangrove forests have significant economic benefit since can contribute to increase total volume of the stand up to $33 \%$. If multi stem trees excluded from calculation (only one stem counted and calculated for each trees), then average volume from the stands decreasing significantly become $233.79 \mathrm{~m}^{3} \mathrm{ha}^{-1}$ instead of $310.99 \mathrm{~m}^{3} \mathrm{ha}^{-1}$. Phenomena of multi stem trees in secondary mangrove forests is also occurred in managed mangrove of Matang, Malaysia which has been managed for timber extraction since early 1900 for charcoal production [21],[23]. Further observation on these multi stem trees need to be carried out because mangroves have characteristic of extensive natural thinning [21],[23]-[25], thus loss of standing stock could be prevented while taking early benefit from the stands by conducting artificial thinning if necessary.

Significant growth of secondary mangrove forests indicates that mangrove ecosystem has resiliency for long-term timber utilization because of high survival rate as distinctive character of this ecosystem and supported by the benefits of multi stem tress from secondary forests. Propagules of R. apiculata and R. mucronata which planted directly on the mangrove site of Bintuni Bay have survival rates of $81 \%$ and $90 \%$ consecutively [26]. Results of this study show that after 26 years of growth, survival rates of R. apiculata and R. mucronata were $71.70 \%$ and $64.84 \%$ respectively. High survival rates will guarantee the effectiveness of afforestation in order to ensure forest regeneration post-harvesting, while success of afforestation is one of the principles of sustainability in timber management [27].

\subsection{Species Comparison}

The results show that R. apiculata experienced the best growth and provided extremely high potential standing stock, while C. decandra experienced the poorest growth. These differences could be happened because of different growth ability and various morphological characteristic among mangrove species. According [28] found that C. decandra has better opportunities to disperse widely because of slender morphology, low density and small size propagules. However, establishment chance of C. decandra is lower compare to other species due to slower root-growth, desiccation sensitivity and smaller size. Differently, [29] observed that R. apiculata, as the most distinctive species in the genus, is a common and even dominant 
constituent of mangroves in the Melanesian region as far west as Papua New Guinea. In postharvest secondary mangrove forests of Bintuni Bay, this species covering $90 \%$ of total observed species [6] because of its wide range tolerance and easy to grow in a stable and establish mangrove environment [30].

R. apiculata confirms its dominance in mangrove community of Bintuni Bay since this species can perform significant growth and provide total volume of $594.85 \mathrm{~m}^{3} \mathrm{ha}^{-1}$ with average DBH of $12.70 \mathrm{~cm}$ and extractable biomass of 480.24 ton $\mathrm{ha}^{-1}$. Trees density and total stem density of R. apiculata in the age was estimated to be 2,581 tree $^{-1} \mathrm{a}^{-1}$ and 4,925 stem ha ${ }^{-1}$ consecutively (Table 1). Density of multi stem trees for R. apiculata in 2 block sample was clearly different which correlated to significant difference $(p>0.001)$ in volume and basal area as well as extractable biomass. Percentage of multi stem trees in the first block sample was $37.82 \%$ from total trees individual, while in the second block was $66.37 \%$.

Table 1 Mean forest structure (volume $\left(\mathrm{m}^{3} \mathrm{ha}^{-1}\right)$, basal area $\left(\mathrm{m}^{2}\right)$, DBH $(\mathrm{cm})$, trees density $\left(\right.$ trees $\left.\mathrm{ha}^{-1}\right)$ and total stem $\left(\right.$ stem ha $\left.{ }^{-1}\right)$ ), biomass $\left(\right.$ ton $\mathrm{ha}^{-1}$ ) and survival rate $(\%)$ of 26-year-old planted mangroves for 5 dominant and commercial species in Bintuni Bay, West Papua, Indonesia

\begin{tabular}{clccccccc}
\hline No & \multicolumn{1}{c}{ Species } & Volume & $\begin{array}{c}\text { Basal } \\
\text { area }\end{array}$ & DBH & $\begin{array}{c}\text { Trees } \\
\text { density }\end{array}$ & $\begin{array}{c}\text { Total } \\
\text { stem }\end{array}$ & Biomass & $\begin{array}{c}\text { Survi- } \\
\text { val rate }\end{array}$ \\
\hline 1 & R. apiculata & 594.85 & 65.12 & 12.70 & 2581 & 4925 & 480.24 & 71.70 \\
2 & R. mucronata & 537.69 & 52.92 & 15.96 & 2334 & 2538 & 434.09 & 64.84 \\
3 & B. parviflora & 294.76 & 32.80 & 11.50 & 1944 & 2694 & 218.96 & 53.99 \\
4 & B. gymnorhiza & 98.78 & 22.11 & 6.95 & 2600 & 5341 & 79.01 & 72.22 \\
5 & C. tagal & 28.89 & 6.82 & 5.43 & 1253 & 2334 & 23.11 & 34.81 \\
& Average & 310.99 & 35.95 & 10.32 & 2143 & 3566 & 247.08 & 59.51 \\
\hline
\end{tabular}

Survival rate of R. apiculata $(71.70 \%)$ was slightly below B. gymnorhiza $(72.22 \%)$ in terms of total individual trees that survived after 26 years. Survival rate of B. gymnorhiza was the highest but this species provided relatively low standing stock (second lowest before C. decandra) and only contributed to increase total stem density since $65.87 \%$ of the trees were categorized as multi stem trees. Total individual of B. gymnorhiza was 2,600 trees ha ${ }^{-1}$ while total stem density of this species was 5,341 stem ha ${ }^{-1}$ (Table 1). R. apiculata has $53.13 \%$ of total tress individual categorized as multi stem trees, while B. parviflora, C. tagal, and R. mucronata have $20.79 \%$, $21.39 \%$ and $6.85 \%$ consecutively. Total stem density depends on the occurrence of multi stem trees that could vary between species and planting location.

\subsection{Implications for Forest Management}

After using parent trees method for silviculture system implementation in the first 30-year rotation cycle, the FME will use clear-cut method with artificial regeneration in the second rotation so there would be no more parent trees left in logged-over area [9]-[10]. Clear cut method is one of several options allowed in the Government regulation (year: 2016) regarding mangrove silviculture system [31] that replaced former regulation (year: 1978) which adopted 
parent trees method [11]. The new silviculture system no longer depends on parent trees as natural propagule suppliers, which can provide around 1,021 seedlings $\mathrm{ha}^{-1}$ to the logged-over area [32]. Therefore, post-logging afforestation has significant role to ensure mangrove regeneration because supply of seedlings from parent trees no longer available. Source of natural seedlings will only available from surrounding unharvest area since $73 \%$ of annual block are still intact due to low harvest rate on each year [1].

After logging activity with clear cut method is finished in harvested block, species which planted in logged-over area should be considered appropriately to ensure the production aspect (sustainability of forest utilization) and from the ecological aspect should not alter the dominance of species between pre- and post-harvest conditions. Results of this study indicate that afforestation using R. apiculata and R. mucronata is appropriate because survival rate of these two species were relatively high and were able to provide optimal standing stock compared to other species (Table 2). R. apiculata as the most dominant species in mangrove forests of Bintuni Bay [1],[13] is strengthening its dominance due to its growth ability which cannot be competed by other species.

Planting using other three species (B. gymnorhiza, B. parviflora and C. tagal) should also be done in order to maintain the biodiversity of mangrove flora in Bintuni Bay so that secondary forests would not become homogeneous stands of R. apiculata. Five species planted in the permanent plot are 5 dominant species in both primary and secondary mangrove forests within the concession area [1],[13]. Considering that mangroves are naturally given as poor biodiversity ecosystems [30], afforestation in logged-over area in the new silviculture system which adopted clear-cut harvest method should be prioritized using 5 species tested in this study because of their ability to grow and provide sufficient standing stock without changing the dominance of flora in mangrove ecosystem of Bintuni Bay.

\section{Conclusion}

Five mangrove species as commercial and dominant species in Bintuni Bay experienced various growth dynamics with R. apiculata being species with the highest growth rate. In general, forest structure was not impacted by different spacing type. Multi stem trees have significant contribution to increase total volume and extractable biomass of the stands. As the silviculture system for mangrove utilization currently changed into clear-cut with artificial regeneration, 5 species tested in this study are appropriate to be planted in logged-over area since these species could become mature and potential stands for future utilization without altering species domination within the ecosystem. 


\section{Acknowledgment}

Author would like to thank Ir. Susilo Budi Prasetya (former Forestry Manager of PT. BUMWI), Ir. Fairus Mulia (PT. Kandelia Alam) and Dr. Rudhi Pribadi (Universitas Diponegoro) as the initiators and creator of the permanent plot. Special thanks to Research Team of PT. BUMWI for assistance in field work activity.

\section{REFERENCES}

[1] R. P. Yudha, Y. S. Sugito, M. Sillanpää, and S. Nurvianto, "Impact of logging on the biodiversity and composition of flora and fauna in the mangrove forests of Bintuni Bay, West Papua, Indonesia," For. Ecol. Manage., vol. 488, 119038. 2021. https://doi.org/10.1016/j.foreco.2021.119038

[2] Wahyudi, Pemanfaatan \& Pengelolaan Sumberdaya Mangrove di Teluk BintuniPapua Barat, Pohon Cahaya Semesta, Yogyakarta, p.288, 2019.

[3] Indonesia. Director General of Sustainable Production Forest Management: Keputusan Direktur Jenderal PHPL No. SK.62/PHPL/SET.5/KUM.1/12/2020: Pedoman, Standar dan/atau Tata Cara Penilaian Kinerja Pengelolaan Hutan Produksi Lestari, Verifikasi Legalitas Kayu, Uji Kelayakan dan Penerbitan Deklarasi Kesesuaian Pemasok, serta Penerbitan Dokumen V-Legal/Lisensi FLEGT. Ministry of Environment and Forestry, Republic of Indonesia, Jakarta, 2020.

[4] Forest Stewardship Council, The FSC National Forest Stewardship Standard of Indonesia, FSC-STD-IDN-02-2020 EN, FSC International Centre, Bonn, p.137, 2020.

[5] Indonesia. Minister of Forestry: Keputusan Menteri Kehutanan No. SK.213/MenhutII/2007 tentang Perpanjangan Izin Usaha Pemanfaatan Hasil Hutan Kayu Dalam Hutan Alam PT. BUMWI Atas Areal Hutan Produksi Seluas $\pm 82.120 \mathrm{Ha}$ di Provinsi Irian Jaya Barat. Ministry of Forestry, Republic of Indonesia, Jakarta, 2007.

[6] R. P. Yudha and Solehudin, "The dynamics of secondary mangrove forest after harvested for 30 years" (to be published).

[7] Indonesia. Director of Forest Resources Monitoring and Inventory: Surat Direktur Inventarisasi dan Pemantauan Sumber Daya Hutan No. S.372/IPSDH/PSDH/PLA.1/7/2019 tentang Hasil Pemeriksaan Peta Penafsiran Citra Satelit Areal Kerja IUPHHK-HA PT. BUMWI. Ministry of Environment and Forestry, Republic of Indonesia, Jakarta, 2019.

[8] Indonesia. Director General of Sustainable Production Forest Management: Peraturan Direktur Jenderal Pengelolaan Hutan Produksi Lestari No. P.8/PHPL-UHP/2015 tentang Petunjuk Teknis Inventarisasi Hutan Menyeluruh Berkala (IHMB) Pada Usaha Pemanfaatan Hasil Hutan Kayu Pada Hutan Alam dan Hutan Tanaman Industri Dalam Hutan Produksi. Ministry of Environment and Forestry, Republic of Indonesia, Jakarta, 2016.

[9] Indonesia. Minister of Environment and Forestry: Keputusan Menteri Lingkungan Hidup dan Kehutanan No. 268/MenLHK-PHPL/UHP/HPL.1/1/2021 tentang Persetujuan Rencana Kerja Usaha Pemanfaatan Hasil Hutan Kayu dalam Hutan Alam pada Hutan Produksi Periode Tahun 2021-2030 Atas Nama PT. BUMWI Provinsi Papua Barat. Ministry of Environment and Forestry, Republic of Indonesia, Jakarta, 2021.

[10] PT. Bintuni Utama Murni Wood Industries, Management Plan for Forest Utilization (Year of 2021-2030), 2021 (unpublished)

[11] Indonesia. Director General of Forestry: Surat Keputusan Direktur Jenderal Kehutanan No. 60/Kpts/DJ/I/1978 tentang Pedoman Sistem Silvikultur Hutan Payau. Ministry of Agriculture, Republic of Indonesia, Jakarta, 1978.

[12] J. O. Bosire, F. Dahdouh-Guebas, J. G. Kairo, S. Wartel, J. Kazungu, and N. Koedam, "Success rates of recruited tree species and their contribution to the structural 
development of reforested mangrove stands," Mar. Ecol. Prog. Ser., vol. 325, pp. 85-91. 2006. https://doi.org/10.3354/meps325085

[13] M. Sillanpää, J. Vantellingen, and D. A. Friess, "Vegetation regeneration in a sustainably harvested mangrove forest in West Papua, Indonesia," For. Ecol. Manage., vol. 390, pp. 137-146. 2017.

[14] H. S. Innah, "Model System Dinamics Pemanfaatan Hutan Mangrove (Kasus: IUPHHK Mangrove di Teluk Bintuni - Papua)," M.Sc. thesis, Institut Teknologi Bandung, Bandung, Indonesia, 2005.

[15] R. Pribadi, "The Ecology of Mangrove Vegetation in Bintuni Bay, Irian Jaya, Indonesia," Ph.D. thesis, Univ. of Stirling, Stirling, Scotland, 1998.

[16] D. L. A. Gaveau, L. Santos, B. Locatelli, M. A. Salim, H. Husnayaen, E. Meijaard, C. Heatubun, and D. Sheil. "Forest loss in Indonesian New Guinea: trends, drivers, and outlook," bioRxiv. 2021. https://doi.org/10.1101/2021.02.13.431006

[17] M. Ilman, P. Dargusch, P. Dart, and Onrizal, "A historical analysis of the drivers of loss and degradation of Indonesia's mangroves," Land Use Policy, vol. 54, pp. 448-459. 2016. http://dx.doi.org/10.1002/9781119312994.apr0752

[18] BPS Kabupaten Teluk Bintuni, Kabupaten Teluk Bintuni Dalam Angka 2016, BPS Kabupaten Teluk Bintuni, Bintuni, p.340, 2016.

[19] PT. Bintuni Utama Murni Wood Industries, Studi Evaluasi Lingkungan HPH PT. BUMWI di Kabupaten Manokwari Propinsi Irian Jaya, 1994 (unpublished)

[20] IDEAS Consultancy Services, Identification of High Conservation Value Area in PT. BUMWI Bintuni Bay West Papua, 2015 (unpublished)

[21] A. Goessens, B. Satyanarayana, T. Van der Stocken, M. Q. Zuniga, H. Mohd-Lokman, I. Sulong, and F. Dahdouh-Guebas, "Is Matang Forest in Malaysia sustainably rejuvenating after more than a century of conservation and harvesting management?" PLoS ONE, vol. 9, no. 8, p e105069. 2014.

[22] M. Tantra, M. Sillanpää, and R. X. Teo. "Revisiting Mangrove Allometry for the Purpose of Sustainable Forest Management in West Papua, Indonesia," presented at the 5th Int. Mangrove, Macrobenthos, and Management Meeting, Singapore. 2019.

[23] W. K. Gong, and J. E. Ong, "The use of demographic studies in mangrove silviculture," Hydrobiologia, vol. 295, pp. 255-261. 1995.

[24] R. Deshar, S. Sharma, A. T. M. R. Hoque, K. Mouctara, and A. Hagihara, "Selfthinning of leaf, wood and aboveground in overcrowded mangrove Bruguiera gymnorrhiza stands in Okinawa Island, Japan," Procedia Environmental Sciences, vol. 13, pp. 982-993. 2012. https://doi.org/10.1016/j.proenv.2012.01.091

[25] A. Pranchai, "Regeneration and self-thinning processes in a restored Rhizophora apiculata plantation in southern Thailand," Agriculture Nat. Resources, vol. 51, pp. 390-394. 2017. https://doi.org/10.1016/j.anres.2017.11.004

[26] PT. Bintuni Utama Murni Wood Industries, Success Rate of Direct Planting Propagules for 5 Dominant Species in Bintuni Bay, 2020, (unpublished)

[27] H. Simon, Perencanaan Pembangunan Sumber Daya Hutan, Timber Management, Jilid 1A, Pustaka Pelajar, Yogyakarta, p 201, 2010.

[28] D. J. R. De Ryck, E. M. R. Robert, N. Schmitz, T. Van der Stocken, D. Di Nitto, F. Dahdouh-Guebas, and N. Koedam, "Size does matter, but not only size: Two alternative dispersal for viviparous mangrove propagules," Aquat. Bot., vol. 103, pp. 66-73. 2012. http://dx.doi.org/10.1016/j.aquabot.2012.06.005

[29] P. B. Tomlinson, The Botany of Mangroves, Cambridge University Press, Cambridge, p 419, 1986.

[30] P. Saenger, Mangrove Ecology, Silviculture and Conservation, Springer-Science+ Business Media, Dordrecht, p.360, 2002.

[31] Indonesia. Director General of Sustainable Production Forest Management: Peraturan Direktur Jenderal Pengelolaan Hutan Produksi Lestari No. P.8/PHPL/SET/3/2016 tentang Pedoman Sistem Silvikultur Hutan Payau. Ministry of Environment and Forestry, Republic of Indonesia, Jakarta, 2016.

[32] PT. Bintuni Utama Murni Wood Industries, Post-Harvest Forest Inventory Report: Block of 2010-2014, 2016, (unpublished) 